\title{
Rond de schuldbelijdenis in de liturgie
}

\author{
K. Deddens (Emeritus)
}

Departement Diaconologie \& Ecclesiologie

Theological College (Canadian Reformed Church)

\section{Hamilton}

Ontario

\section{Abstract \\ About the confession of sins in liturgy}

This study deals with what happens in the first part of the reformed worship service on Sunday mornings. The article offers a historical review of confession practices in the liturgv, especially during the time of the Reformation, particularly concerning the ideas of John Calvin in liturgical respect. In this article it is argued that the first part of Calvin's order of liturgy (the part preceding the prayer serving to open God's Word) formed an organic whole according to the triad: misery, deliverance and thankfulness. Calvin rightly emphasized the element of humility at the very beginning of the worship service. This humility is expressed in the confession of sins, which is to be followed directly by a word of comfort from Scripture and the declaration of forgiveness of sins for believers. Calvin followed this order in Strassbourg from which he was banished from 1538-1541. He, however, was not able to practise this procedure in Geneve after his return, although he advised the churches to keep this order. This study advocates the maintenance, c.q. re-introduction of this apt beginning of Calvin's liturgy at Strassbourg.

\section{Gereformeerd?}

Het is een verblijdende zaak dat vragen met betrekking tot de eredienst in toenemende mate de belangstelling hebben van kerkeraden en ook van gemeenteleden. Wij zijn aan ook blij met het feit dat de generale synode van Ommen (1993) deputaten heeft benoemd inzake de liturgie. Een van de vragen die daarbij ongetwijfeld aan de orde zijn, is ongetwijfeld: is het 
gewenst in de gereformeerde liturgie een aparte plaats toe te kennen aan de 'absolutie' als genadeverkondiging, na voorafgaande schuldbelijdenis?

$\mathrm{Nu}$ zullen sommigen al aanstonds huiverig zijn voor het woord absolutie, als 'roomse' term. Men denkt dan allicht aan de roomse biecht, die uit drie delen bestond: het berouw van het hart, de belijdenis van de mond, en ten slotte de voldoening door een goed werk te doen. $\mathrm{Na}$ deze drie zaken volgde dan de absolutie door de geestelijke, de 'biechtvader'. Maar voor alle duidelijkheid: hoewel de biecht bij Rome onder de sacramenten wordt gerekend, heeft deze geen plaats in de liturgie, en ook de absolutie is een private aangelegenheid tussen biechtvader en boeteling.

Dichterbij de liturgie ligt de belijdenis van schuld en onwaardigheid die in het begin van de Middeleeuwen reeds werd uitgesproken door de dienstdoende priester op de onderste trede van het altaar, het 'trappengebed'. Ten overstaan van zijn assistenten belijdt de priester dan zijn onwaardigheid (Confiteor - ons woord confessie hangt daarmee samen), en dan volgt de toebidding van een soort absolutie. Maar deze valt dan nog buiten de liturgie als zodanig: het is meer een zaak van voorbereiding voor de dienst. (Zie hierover ook Webber, 1938:77 v.v.; cf. Wegman, 1976:86 v.)

Van veel ouder datum was de schuldbelijdenis (en bede om vergeving) die maar niet persoonlijk of vóór de eredienst werd uitgesproken, maar die onderdeel was van de liturgie, en dus een gemeenschappelijk karakter droeg. Die komt al voor in de oude kerk, zoals wij later nog zullen zien. Omdat de reformatie, met name die van Calvijn, pretendeerde terug te gaan tot de oude kerk, willen wij nu eerst terug gaan tot de bakermat van de gereformeerde liturgie.

\section{Bakermat}

Wij schrijven het jaar 1538. Calvijn was toen gedwongen, Genève te verlaten en hij kwam terecht in Straatsburg. Deze 'Europese' stad is toen van het grootste belang geworden voor de ontwikkeling van de gereformeerde liturgie. Had Calvijn tot op dat ogenblik gezwegen over de eredienst en zijn gedachten erover nog nooit ergens vastgelegd? Het antwoord moet ontkennend luiden. Niet alleen hing de verbanning van de reformator uit Geneve ook samen met praktische liturgische kwesties, 
maar tevens moet aan T. Brienen worden toegegeven dat Calvijn reeds in de eerste editie van zijn Institutie een zekere orde had geleverd voor de openbare eredienst, in het bijzonder voor de dienst van Woord en sacrament (Brienen, 1987:83 v.).

Calvijn ging daarbij uit van Handelingen 2:42: "En zij bleven volharden bij het onderwijs der apostelen en de gemeenschap, het breken van brood en de gebeden." Hij vervolgt dan:

Zo moest het altijd geschieden, dat er geen samenkomst der gemeente gehouden werd zonder prediking des Woords, gebeden, uitdeling van het Avondmaal en aalmoezen. Dat deze orde ook bij de Corinthiërs ingesteld was, kan men voldoende uit Paulus' woorden gissen; en het staat vast, dat ze daarna vele eeuwen lang in gebruik geweest is (Calvijn, Institutie IV, 17, 44).

Daarbij is het van belang, te wijzen op het feit dat Calvijn een zekere vrijheid in de liturgie heeft voorgestaan, en de gewetens niet wilde binden aan bepaalde vormen. Op tal van plaatsen verdedigt Calvijn deze vrijheid. Wij beperken ons tot een enkel citaat: “... want het is zeker, dat alle ceremoniën verderfelijk en schadelijk zijn, indien de mensen er niet door tot Christus geleid worden" (Calvijn, Institutie, IV, 10,5).

Het is ook waar dat Calvijn aan deze liturgische principes (concentratie op de hoofdzaken en vrijheid in de ceremoniën) heeft vastgehouden. Toch geloof ik dat de bakermat van de gereformeerde liturgie niet ligt in Basel (waar Calvijn zijn Institutie schreef ), ook niet in Genève (waar hij zo'n groot deel van zijn leven doorbracht), maar in Straatsburg, waar hij slechts drie jaar als banneling verbleef. In Straatsburg gaf Calvijn meer vaste vorm aan een uitgewerkte liturgie, en daar begon hij ook met de psalmberijming, die hij later in Genève voltooid zou zien.

\section{Prediking}

Wat de prediking betreft, Calvijn volgde in Straatsburg de gewoonte die al een aanvang genomen had in het begin van de $16 \mathrm{e}$ eeuw. In 1503 had Johann Ulrich Surgant van Basel een handboek geschreven voor de prediking, waarin hij het pleit voerde dat de erediensten zouden worden verbeterd. Deze verbetering moest beginnen met de verbetering van de prediking. Hij richtte zich in het bijzonder tot de jonge mannen, die als predikers nog aan het begin van hun loopbaan stonden. Hij gaf ook een 
beschrijving van de prediking zoals die in zijn dagen in praktijk werd gebracht, zowel in Basel als in enkele dorpen in de Elzas. Deze prediking geschiedde volledig in de Duitse taal, en niet meer in het Latijn.

Belangrijk was ook dat de Tien Geboden in deze liturgie een plaats hadden. Surgant bleef op het punt van de kerk de roomse leer toegedaan, maar er waren bij hem reformatorische trekken. Zijn boek speelde dan ook een belangrijke rol toen in de dagen van de reformatie pogingen werden ondernomen om de eredienst te vernieuwen (Dankbaar, 1987:201 v.v.). Voor ons onderwerp is van belang dat Surgant (Weismann, 1956:24) spreekt over de Offene Schuld die een plaats had in de eredienst, helemaal aan het slot, na de preek. Deze wordt aldus ingeleid:

Opdat uw gebed en andere goede werken voor God des te aangenamer zouden zijn, en u de aflaat en de genade deelachtig moogt zijn, zoals deze komt van het Woord van God en van dit huis van God, zo laat ons de openbare schuldbelijdenis uitspreken met een berouwvol hart en het kruisteken maken.

Daarna volgen dan gebeden, waarin zonden worden genoemd en sprak de voorganger een absolutie uit in de vorm van een soort voorbede. Men ziet: Roomse vormen blijven nog bestaan! De ontwikkeling in Straatsburg gaat echter door. Op 16 februari 1524 - zelfs nog vóór Martin Luther - draagt Theobald Schwarz in Straatsburg de mis helemaal in de Duitse taal op. Maar het is dan een gezuiverde mis, en de terminologie van de Offene Schuld is beter dan die van Surgant. In het gebed wordt verwezen naar Psalm 51 en een soort absolutie wordt gegeven door een citaat uit 1 Timoteüs 1:15: "Christus Jezus is in de wereld gekomen om zondaren te behouden."

Opgemerkt mag nog worden dat in de liturgie van Schwartz nog wel meer reformatorische elementen aanwezig waren, zoals bijvoorbeeld het toedelen van zowel brood als wijn bij de viering van het Avondmaal.

\section{Martin Bucer}

In hetzelfde jaar dat Theobald Schwartz in Straatsburg reformatorische veranderingen doorvoerde in de liturgie, ontvouwde Martin Bucer daar zijn liturgisch programma in zijn geschrift Grund und Ursach auss gotlicher Schrifft der Neuerungen von dem Nachtmahl des Herrn, dem auf den Feiertagen, etc. Hij spreekt daarin over de vernieuwingen die in 
Straatsburg in de liturgie hebben plaatsgevonden. In het tweede hoofdstuk geeft hij een beschrijving van de eredienst zoals die in Straatsburg werd gehouden:

Als de gemeente op zondag samenkomt, vermaant de dienaar het volk, hun zonden te belijden en te bidden om vergeving. Namens de hele gemeente, doet hij dan belijdenis voor God, bidt om vergeving en spreekt absolutie uit voor de gelovigen. Daarna zingt de gemeente enkele korte psalmen of hymnen. Dan spreekt de dienaar een kort gebed uit, leest voor de gemeente een passage voor uit de geschriften van de apostelen en legt deze zo kort mogelijk uit. Daarna zingt de gemeente opnieuw, ditmaal de Tien Geboden of iets anders. Hierna leest de dienaar het evangelie en houdt de eigenlijke preek. Nadat de preek is geeindigd, zingt de gemeente de Artikelen van ons geloof (de Apostolische geloofsbelijdenis op rijm), de dienaar doet een gebed voor de overheid en voor alle mensen, in het bijzonder voor de gemeente die daar tegenwoordig is, terwijl hij smeekt om een toenemen in geloof, liefde en genade om Christus' dood met eerbied in gedachtenis te houden. Daarna vermaant hij degenen die met hem het Avondmaal willen vieren, aan hun zonde te sterven, hun kruis gewillig te dragen, en dat zij mogen gesterkt worden in hun geloof met het $0_{g}$ op wat moet geschieden als wij met gelovige harten overdenken welke grondeloze genade en goedheid Christus aan ons heeft getoond daarin dat Hij voor ons Zijn lichaam en bloed aan het kruis offerde aan Zijn Vader. Na deze aansporing leest hij het evangelie met betrekking tot het Avondmaal, zoals de drie evangelisten het hebben beschreven en ook de apostel Paulus in 1 Corintiërs 11. Daarna deelt de dienaar het brood en de beker onder hen uit, nadat hij ook zelf ervan genomen heeft. De gemeente zingt dan opnieuw een iofzang, en daarna sluit de dienaar het Avondmaal met een kort gebed, zegent het volk en laat hen gaan in de vrede van de Here. Dit is de wijze en de gewoonte waarmee wij thans het Avondmnal des Heren vieren op de zondag alleen (zie Maxwell, 1952:100 v.v.).

\section{Begin van de dienst}

Wij hebben een beschrijving van het eerste gedeelte van de dienst zoals Calvijn die aantrof toe hij in 1538 in Straatsburg kwam. (Het gaat dan om de dienst van Bucer in het Duits, terwijl hij zelf de Fransspreker, de gemeente ging dienen.) Vijf punten gingen aan de preek vooraf:

* Als de gemeente bijeen is, komt de dominee (Pfarrer) binnen, gaat naar de tafel (Altartisch) met het gezicht naar de gemeente en spreekt de volgende woorden staande, zodat iedereen het kan horen: 
Doet belijdenis voor God en laat elk zijn zonden en ongerechtigheid erkennen:

Almachtige God, eeuwige Vader, wij erkennen en belijden voor $U$ dat wij ontvangen zijn in ongerechtigheid en dat ons hele leven vol is van zonde en overtreding, daarin dat wij nie met vreugde Uw Woord hebben geloofd, noch heilige geboden zijn nagekomen. Wees ons genadig terwille van Uw goedheid en Uw Naam, zo smeken wij $U$, en vergeef ons onze ongerechtigheid, die zeer groot is.

* Dan spreekt hij een absolutie of vertroostend woord naar 1 Timoteus 1:

Dit is een getrouw woord en alle aanneming waard, dat Christus Jezus in de wereld gekomen is om zondaren te behouden. Laat ieder in zijn hart instemmen met de heilige Paulus in waarheid en geloven in Christus. In Zijn Naam spreek ik dan vergeving van al uw zonden tot $u$ uit, en ik verklaar $u$ dat $u$ daarvan op aarde bent ontbonden zodat $u$ daarvan ook ontbonden bent in de hemel voor eeuwig. Amen.

Soms gebruikt hij andere woorden die ons vertroosten in de vergeving van zonden en in het rantsoen van Christus voor onze zonden, zoals Johannes 3: 16, of 3:35 en 36, of Handelingen 10:43, of 1 Johannes 2:1 en 2.

* Daarna begint de kerk een psalm of een hymn te zingen in plaats van de Introitus. Soms volgt daama het Kyrie eleison en het Gloria in excelsis.

* $\quad$ Als dit heeft plaatsgevonden, spreekt de dienaar (Diener) een kort gebed uit om genade en een rechte geest, opdat het Woord van God en de prediking die nu volgen, mogen worden gehoord met vruchtbaar resultaat. De inhoud van dit gebed is gebaseerd op zulke verlangens die een christen behoort te hebben, en is gewoonlijk ontleend aan de preek die daarna volgt. Als voorbeeld kan het volgende dienen:

De Here zij met $u$.

Laat ons bidden.

Almachtige, immer genadige Vader, aangezien heel onze zaligheid ervan afhangt dat wij waarachtig Uw heilig Woord hebben verstaan: geef dat onze harten mogen bevrijd worden 
van wereldse zaken, zodat wij met ijver en geloof Uw heilig Woord horen en begrijpen, dat wij daarbij Uw heilige wil recht mogen verstaan, en in alle ernst daarnaar mogen leven tot prijs en glorie van Uw Naam; door onze Here Jezus Christus. Amen.

Dan zingt de kerk een psalm of een of meer verzen en de dienaar gaat de kansel op en leest uit een van de evangeliën een gedeelte in volgorde, en kiest daar zoveel uit als hij van plan is te verklaren in een preek (zie Maxwell, 1952:102 v.v.).

\section{Calvijn in de Franse gemeente}

In de Franse vluchtelingengemeente van Straatsburg volgde Calvijn de orde die Bucer in de Duitssprekende gemeente daar had ingevoerd. Maar het dient te worden gezegd dat hij niet slaafs deze orde volgde. Het begin van de dienst was als volgt:

* Inroepen van Gods hulp naar Psalm 121:2.

* Belijdenis van zonde.

* Woorden van vergeving uit de Schrift om de gewetens te troosten met de absolutie, de woorden van kwijtschelding en vergeving.

* Zingen van de Wet van Gods verbond door de gemeente (de aanspraak van God en de eerste tafel van de wet van God in een berijming van Exodus gezongen met een Kyrie eleison na elk gebod).

* Kort gebed.

* $\quad$ Zingen van de Wet (de tweede tafel, op dezelfde wijze als de eerste tafel).

* Gebed van de dienaar (nu van de kansel), eindigend met het Onze Vader, als het gebed voor de opening van Gods Woord.

$\mathrm{Na}$ dit gebed voor de verlichting van de Heilige Geest volgt de lezing van de Schrift en de prediking van Gods Woord.

Het is opmerkelijk dat de belijdenis van zonden (en de daaropvolgende absolutie) helemaal aan het begin van de dienst plaats vindt. Calvijn gebruikte de volgende woorden: 
Almachtige, eeuwige God en Vader, wij belijden en erkennen dat wij, helaas, in zonden zijn ontvangen en geboren, en dat wij daarom geneigd zijn tot alle kwaad en traag tot alle goed; dat wij zonder ophouden Uw heilige geboden overtreden en steeds nog meer onszelf bederven. Maar wij hebben hierover berouw en smeken $U$ om Uw genade en hulp. Heb daarom medelijden met ons, zeer barmhartige God en Vader, door Uw Zoon, onze Here Jezus Christus. Verleen ons en vermeerder in ons uw Heilige Geest, opdat wij uit de grond van ons hart onze zonde en ongerechtigheid mogen erkennen, oprecht berouw en droefheid voor de zonde verwerven, volledig aan de zonde afsterven, en ten volle behagen door een nieuw godvruchtig leven. Amen (zie Maxwell, 1952:103; ook Van Rongen, 1990:40).

De woorden van absolutie die volgen op woorden uit de Schrift over vergeving luiden als volgt:

Een ieder van u moet zichzelf erkennen als zondaar en zich vernederen voor God. Hij moet geloven dat de hemelse Vader hem genadig wil zijn. Aan ieder van hen die op deze wijze berouw hebben en Jezus Christus tot hun behoud zoeken, verkondig ik vergeving in de naam van de Vader, de Zoon en de Heilige Geest. Amen.

Er waren eigenlijk slechts geringe verschillen tussen Bucer's liturgische orde van de Duitse gemeente en die welke Calvijn gebruikte in de Franse gemeente van Straatsburg. Het belangrijkste verschil betreft het begin van de dienst. Bucer begon aanstonds met de schuldbelijdenis, terwijl Calvijn de dienst aanving met Psalm 121:2 (of zoals sommigen zeggen: Psalm 124:8). Een ander verschil betreft de Wet van Gods verbond die Calvijn liet zingen aan het begin in plaats van een psalm of een hymn. Aan die zang verbond Bucer dan soms het Kyrie eleison, dat door Calvijn steeds gebruikt werd na elk afzonderlijk gebod. Maar beiden benadrukten sterk de vier voomaamste elementen van de eredienst: Woord, sacrament, gebed en zang.

\section{Schuldbelijdenis aan het begin}

Calvijn was de mening toegedaan dat de orde van de eredienst, waarbij de gemeenschappelijk schuldbelijdenis aanstonds aan het begin van de dienst plaats vond, van groot belang was. In zijn Institutie (III, 4, 11) schrijft hij daarover als volgt:

De gewone belijdenis (van schuld, K.D.) zal niemand met gezond verstand, behalve dat ze door de mond des Heren aangeprezen is, durven afkeuren, wanneer hij haar nut overwogen heeft. Want daar wij in alle heilige 
samenkomsten ons stellen voor het aangezicht Gods en der engelen, welk ander begin zal dan onze handeling hebben dan de erkenning onzer onwaardigheid? Maar, zult ge zeggen, die geschiedt in elk gebed. Want zo dikwijls als wij om vergeving bidden, belijden wij onze zonden. Ik erken dat; maar indien gij overweegt, hoe groot onze zorgeloosheid, of slaperigheid, of onverschilligheid is, zult gij mij toestemmen, dat het een heilzame instelling zou zijn, indien het Christenvolk door een plechtig gebruik om te belijden geoefend werd tot verootmoediging. Want ofschoon de ceremonie, die de Here de Israëlieten voorschreef, behoorde tot de opvoeding naar de wet, heeft toch de zaak zelf ook op ons enigszins betrekking. En voorzeker wij zien, dat deze gewoonte in welgeaarde kerken met vrucht waargenomen wordt, dat op iedere dag des Heren de dienaar een formulier van belijdenis in zijn naam en in naam van het volk uitspreekt, waarin hij allen schuldig stelt aan ongerechtigheid, en de Here om vergiffenis bidt. Eindelijk door deze sleutel wordt de deur geopend om te bidden, zowel voor een ieder persoonlijk, als voor allen in het openbaar.

In dit opzicht wijst Calvijn ook op het voorbeeld van de Heilige Schrift. Niet alleen persoonlijk moet schuld worden beleden, maar ook gemeenschappelijk, in de gemeenschap der heiligen:

Van deze gemeenschappelijke schuldbelijdenis hebben wij een voorbeeld in die plechtige belijdenis, die het ganse volk aflegt onder leiding van Ezra en Nehemia. Want daar die langdurige ballingschap, de verwoesting van de stad en de tempel en de verstrooiing van de godsdienst, de gemeenschappelijke straf was geweest voor alle afval, konden zij de weldaad van de bevrijding niet naar behoren erkennen, indien zij zich niet van te voren schuldig verklaarden. En het doet er niet toe of in een gemeente soms enige weinigen onschuldig zijn; want aangezien zij leden zijn van een ziek en slecht gesteld lichaam, moeten zij niet roemen van gezondheid. Ja het is onmogelijk, dat zij ook niet enigszins besmet zijn en zo niet ook zelf enige schuld dragen (Institutie, III, 4, 11).

Calvijn was er van overtuigd dat hij met de nadruk op openbare schuldbelijdenis in de lijn van de vaderen was. Chrysostomus, de bekende kerkvader die door Calvijn vaak geciteerd wordt, had in het jaar 390 in een preek over het evangelie naar Matteüs de uitspraak gedaan dat de eerste gebeden in de openbare eredienst altijd een bede om schuldvergeving moesten inhouden, en ook een beroep op Gods barmhartigheid. Calvijn was van oordeel dat ook de schuldvergeving een uiterst belangrijke zaak was:

In de artikelen des geloofs wordt het artikel over de vergeving der zonden passend vastgeknoopt aan het artikel over de kerk. Want deze vergeving 
verkrijgen alleen haar burgers en huisgenoten, gelijk men leest bij de profeet (Jes. 33:24). Dus moet de opbouwing van het hemelse Jeruzalem voorgaan, waarin dan deze goedertierenheid Gods plaats moge hebben, dat de ongerechtigheid van allen, die zich tot haar begeven hebben, wordt uitgewist. Ik zeg echter, dat de kerk eerst moet worden gebouwd niet omdat er enige kerk zonder vergeving der zonden zijn kan, maar omdat de Here zijn barmhartigheid slechts in de gemeenschap der heiligen beloofd heeft. De vergeving der zonden, zonder welke wij geen verbond of gemeenschap met God hebben, is dus voor ons de eerste ingang tot de kerk en het Koninkrijk Gods.

\section{Calvijn citeert dan Hosea 2:17 en vervolgt:}

Wij zien, hoe de Here door zijn barmhartigheid ons met zich verzoent. Zo zegt Hij ook elders (Jer. 33:8), waar Hij voorzegt dat het volk dat Hij verstrooid had, weer verzameld zal worden: 'Ik zal hen reinigen van al hun ongerechtigheid, met dewelke zij tegen Mij gezondigd hebben'. Daarom worden wij tot de gemeenschap der kerk aangenomen door het teken der afwassing, opdat wij daardoor zouden leren, dat de toegang tot Gods huisgezin niet voor ons openstaat, tenzij eerst door zijn goedheid onze vuilheden afgewast worden. Maar niet alleen ontvangt de Here ons door de vergeving der zonden eenmaal in zijn kerk en neemt Hij ons in haar op, maar ook bewaart en beschermt Hij ons in haar door diezelfde vergeving. Want waartoe zou het dienen dat wij een vergiffenis kregen, die ons tot generlei nut zou strekken? En dat de barmhartigheid des Heren doelloos en bedrieglijk zou zijn, wanneer ze slechts eenmaal verkregen werd, kan iedere vrome voor zichzelf getuigen; want een ieder is zich zijn ganse leven door bewust van vele zwakheden, die Gods barmhartigheid nodig hebben. En ongetwijfeld belooft God deze genade niet tevergeefs aan zijn huisgenoten in het bijzonder, en niet tevergeefs beveelt $\mathrm{Hij}$, dat deze zelfde boodschap der verzoening hun dagelijks gebracht moet worden. Daarom, indien wij niet, gelijk wij de overblijfselen der zonde gedurende ons ganse leven omdragen, door de voortdurende genade des Heren, die Hij betoont in het vergeven der zonden, gesteund worden, zullen wij ternauwemood een ogenblik in de kerk blijven. Maar de Here heeft de zijnen geroepen tot eeuwige zaligheid; zij moeten dus bedenken, dat voor hun zonden altijd vergiffenis bereid is. Daarom moeten wij voor zeker houden, dat door Gods milddadigheid, en door de tussenkomst van Christus' verdienste, en door de heiligmaking des Geestes, ons, die in het lichaam der kerk zijn aangenomen en ingelijfd, kwijtschelding van onze zonden geschied is, en nog dagelijks geschiedt (Institutie, IV, 1, 20 v.v.). 


\section{Terug naar de oude kerk!}

Calvijn was zich terdege bewust dat in de prediking de sleutels van het Koninkrijk der hemelen bediend werden en dat die prediking zelf bediening der verzoening is. In het vervolg van zijn Institutie gaat hij daar dan ook uitvoerig op in. Maar tegelijk hechtte hij veel aan een afzonderlijk element van schuldbelijdenis aan het begin van de openbare eredienst, omdat de gemeente schuldig voor God verschijnt, en die schuld heeft te erkennen. Deed Calvijn dat omdat hij deze gang van zaken nu eenmaal in Straatsburg aantrof? Omdat hij zelf niet zo inventief was, en daarom de draad vervolgde van de Middeleeuwen met de Offene Schuld? Nee. In de eerste plaats baseerde Calvijn zich op de Schrift, ook wat de liturgie betreft. Vandaar zijn soberheid in liturgische zaken. Maar vandaar ook zijn onverdroten beroep op teksten uit het Oude en Nieuwe Testament als het gaat om zaken die van wezenlijk belang zijn voor het samenkomen van God met Zijn volk. Maar er is meer. Calvijn was een reformator. Reformatie betekende voor hem niet alleen terugkeer tot de Schrift, maar ook: terugkeer tot de oude kerk, met afzwering van de deformatie die in de loop van de tijd steeds sterkere vormen had aangenomen. Vandaar zijn voortdurend beroep op $L$ 'église ancienne, de jonge Pinksterkerk met haar aanvankelijk gunstige ontwikkeling. Waarom citeert Calvijn zo dikwijls de apostolische vaders en de kerkvaders? Omdat hij er stellig van overtuigd was dat zij zich nog dikwijls bewogen in de Schriftuurlijke lijn, waarvan Rome zich steeds meer verwijderd had. In het kader van ons onderwerp willen we dit nagaan op vier elementen van het begin van de eredienst, $\mathrm{nl}$ :

* Belijdenis van zonden.

* Vergeving van zonden.

* Gods verbondswoorden.

* Het Kyrie eleison.

\subsection{Belijdenis van zonden}

Wij zagen al dat Calvijn grote nadruk legde op de gemeenschappelijk schuld die de gemeente heeft en dat hij dit baseerde op de Schrift. Daarmee ontkende Calvijn niet de persoonlijke schuld, die ieder lid van de 
gemeente heeft. Maar dat is niet een zaak tussen dit gemeentelid en de 'geestelijke', waar een sacramentele biecht aan te pas komt. Nee, Calvijn ging verder aan Luther in dit opzicht, en wilde van deze biecht niets weten. Hij baseerde dat vooral op Jacobus 5:16, waaruit hij twee dingen afleidde: wij moeten onze zonden belijden voor God en hem om vergeving vragen; en wij moeten onze zonden belijden tegenover de naaste, die wij tekort gedaan hebben. Dat is dan de persoonlijke schuld. Maar hoe ging het nu verder in de oude kerk, wat de gemeenschappelijke schuld betreft? Wij beginnen met het eind van de eerste eeuw, kort na de dood van de langst levende apostel Johannes. Men neemt aan dat omstreeks het jaar 96 een brief naar de kerk te Corinthe is gezonden door een zekere Clemens uit Rome. Daarin treffen wij het volgende gebed aan:

$O$, Barmhartige en Medelijdende, vergeef ons onze zonden en ongerechtigheid, overtredingen en tekortkomingen. Reken ons niet toe iedere zonde van Uw knechten en dienstmaagden, maar reinig ons met de reiniging van Uw waarheid en leid onze voetstappen om onze weg in heiligheid te vervolgen en te doen wat ons en onze oversten goed en welgevallig is.

Wij zijn het eens met A.B. Macdonald die opmerkt dat de uitdrukking "knechten en dienstmaagden" een indicatie is in de richting van de publieke eredienst (Macdonald, 1935:100).

Een tweede voorbeeld kunnen we nemen uit de Didachè ("De leer van de twaalf apostelen"), eveneens uit het eind van de eerste eeuw, of anders niet lang daarna. Daarin vinden we een publieke schuldbelijdenis door de gemeente:

In de samenkomst zult $u$ uw zonden moeten belijden en u zult niet met een slecht geweten mogen opgaan tot het gebed (IV, 14) .

Dat geldt niet alleen voor het eerste deel van de eredienst, maar ook voor het tweede gedeelte, waarin de viering van het Avondmaal plaats vindt:

Op de dag des Heren samengekomen, zult u brood breken en dankzegging doen, na tevoren uw zonden te hebben beleden, opdat uw offer rein mag zijn (IV, 1).

Dat was nog in de begintijd van de christelijke kerk. Maar in de loop van de tijd kwam de nadruk steeds meer te liggen op het persoonlijke gebed van de priester, waarin schuld werd beleden, en vooral op de persoonlijke 
boetedoening in allerlei vormen, waaruit dan ten slotte de biecht is gegroeid.

Maar in Straatsburg zei Bucer: belijd persoonlijk schuld voor God en voor de mensen tegen wie $u$ gezondigd hebt en laat de zondagse dienst aanvangen met een gemeenschappelijke schuldbelijdenis. Calvijn zei hem dit na, en wilde daarmee terugkeren tot de Schrift en tot de oude kerk.

\subsection{Vergeving van zonden}

Belijdenis van zonden en vergeving van zonden hangen nauw samen. Bucer ging hierin voor en Calvijn volgde hem ook daarin na in Straatsburg. Calvijn plaatste dan ook de vergeving der zonden, de absolutie, onmiddellijk na de belijdenis der zonden. Evenals Schwarz citeerde Bucer hiervoor 1 Timoteus 1:15 dat Christus Jezus in de wereld gekomen was om zondaren te behouden. Maar we zagen al dat verscheidene andere teksten uit het Nieuwe Testament in aanmerking kwamen om in verband met de schuldvergeving aangehaald te worden. Verder heeft Bucer in zijn verdere bewijsvoering gewezen op nog meer teksten uit de Schrift. Hij wees de roomse gedachte van een sacramentele handeling volledig van de hand en wilde ook niet weten van aanroeping van heiligen om tot vergeving te komen. Bij hem - en ook bij Calvijn lag aan de absolutie als element in de eredienst de gedachte ten grondslag dat God een gaarne vergevend God is, die de zonden kwijtscheldt als men daarom bidt en daarvoor dankt.

\subsection{Gods verbondswoorden}

$\mathrm{Na}$ het woord van troost uit de Heilige Schrift met het oog op de vergeving der zonden, volgde bij Calvijn het zingen van de Decaloog door de gemeente. Hiermee werd de overgang gemaakt van de schuldvergeving naar de dankbaarheid. Men kan terecht zeggen, dat het zingen van de verbondswoorden van God geschiedde "om de gemeente tot het bewustzijn te brengen, dat, uit dank voor die schuldvergeving, heilig voor Gods aangezicht te wandelen plicht was" (Kruijf, 1901:76).

Intussen vergete men niet dat hier de wet niet alleen fungeerde als regel der dankbaarheid, maar dat ook het element van kenbron van ellende nog 
steeds een rol speelt, getuige het steeds herhaalde Kyrie eleison na elk gebod, waarop wij nog terugkomen.

Calvijn liet een berijmde versie van de wet zingen en hij was zelf de dichter daarvan. Voor hem waren de geboden onlosmakelijk verbonden aan Gods beloften. De aanhef was voor hem niet een soort introductie, maar wezenlijk bestanddeel van Gods verbondswoorden, waarin de Here zich presenteerde als de belovende God van het verbond: "Ik ben de Here Uw God ...".

Exodus 20:2 is geen 'Inleiding' in den zin van de inleidende coupletten. der berijmingen. Ex. 20:2 is de hoofdzaak: Gods liefdedaad, Gods actie. Daarop behoort te volgen 's mensen liefdedaad, zijn reactie (Hasper, 1955: 592).

In het licht van de vergeving van de vergeving van de zonden en de kwijtschelding van de schuld, en ook in het licht van Gods belofte dat $\mathrm{Hij}$ in Christus zijn volk uit het diensthuis van de zonde leidt, moet nu zijn volk leven naar de eis van Gods verbond. In verband daarmee is het laatste couplet ook opmerkelijk, dat niet direct ontleend is aan de tekst van Exodus 20:

\author{
Dieu, qui ae toute saincteté, \\ contiens seul la vertu en toy, \\ à la Justice de ta Loy, \\ veuilles noz meurs conformer. \\ ( $O$ God, die alleen het vermogen \\ bezit van alle heiligheid, \\ laat ons gedrag zijn overeenkomstig \\ de gerechtigheid van Uw wet).
}

Calvijn volgde in deze berijming die van Luther: "Dies sind die heiligen zehn Gebot." Maar hij volgde Luther niet in de toevoeging van een couplet dat ontleend was aan het Nieuwe Testament, waarin de hulp van de middelaar Jezus Christus werd ingeroepen.

De gedachte van een gezongen Wet was niet nieuw: tijdens Calvijns eerste verblijf in Genève moet hij al bekend zijn geweest met een Franse berijming van de Tien Geboden, die daar in 1532 was bezorgd en van de hand was van een zekere Antoine Saunier (Hasper, 1955:444). 
Veel ouder is natuurlijk de voorlezing van de wet in de eredienst. Niet alleen valt hier te denken aan de lezing van de Thorah in de synagoge, maar er zijn ook aanwijzingen dat de wet een rol speelde in de oude kerk:

Toen de gnostieken optraden, steeds sprekend van vertrouwen op - naar weinig van vreeze voor God - meende men de Wet meer op de voorgrond te moeten plaatsen, en reeds eer men sporen vindt van het voorlezen van den Decaloog bij de samenkomsten, schijnt men hem in de harten van jongen en ouden ingezongen te hebben (Kruijf, 1901:76).

Kruijf verwijst in zijn Liturgiek dan naar de Apostolische Constitutie (II, 25) uit de vierde eeuw, die ten dele zelfs teruggegaan tot de tweede eeuw. Van belang is de plaats van de wet bij Calvijn. In Zürich bv. was de lezing van de wet geplaats aan het eind van de dienst, samen met het Onze Vader en de Apostolische geloofsbelijdenis, "opdat deze drie stukken, het gebed, het gebod en het geloof het eenvoudige volk goed ingeprent zouden worden" (Heyns, 1903:101). Maar Calvijn liet de wet aan het begin zingen, na schuldbelijdenis en absolutie, en wel als regel van de dankbaarheid, hoewel tegelijk het element van kenbron van ellende niet ontbrak door het zingen van Kyrie eleison na elk gebod afzonderlijk. Maar het zingen van de wel kwam dan feitelijk in de plaats van het Groot Gloria, dat eeuwenlang gezongen was na de Introitus en dat ontleend was aan de engelenzang uit Lukas 2: "Ere zij God ...".

Dat Gloria had als ondertoon de dank aan God, die Zijn Zoon in deze wereld gezonden had met het oog op de verlossing van mensenkinderen. Op het Kyrie Eleison komen we nog terug, maar overheersend was dus de gedachte aan dankbaarheid: de lof van God. Iets daarvan vinden wij nog terug in Gezang 1 van het Gereformeerd Kerkboek (voorheen het slotvers 9, thans couplet 13), dat aldus luidt:

Geef dat wij trouw uw wet betrachten.

Gedenk ons in barmhartigheid.

Schenk ons in Christus nieuwe kgachten

tot liefdedienst uit dankbaarheid

49 Afgedacht van de vraag of het zingen van de wet gewenst is, vormt de lengte van dit gezang $0 . i$. wel een bezwaar. 


\subsection{Het Kyrie eleison}

$\mathrm{Na}$ iedere strofe van de Decaloog liet Calvijn het Kyrie eleison zingen door het volk. $\mathrm{Na}$ het zingen van de eerste tafel van de wet deed hij een kort gebed, en in het geheel zong de gemeente twaalf maal: "Here, ontferm U". Ook in dit opzicht volgde Calvijn niet alleen de gewoonte in Straatsburg, maar hij volgde ook Luther na, die eveneens het Kyrie eleison had verbonden met het zingen van de wet. Van Luther zijn twee versies bekend, een in twaalf en de ander in vijf strofen, maar telkens loopt elk couplet uit op een Kyrioleis (Luther, 1950:21 v.v.). Dit Kyrioleis komt bij Luther veel vaker voor in zijn geestelijke liederen, vooral als de geboorte van Christus wordt bezongen:

Gelobet seist du, Jesus Christ,

Dass du Mensch geboren bist

Von einer Jungfrau, das ist wahr,

Des freuet sich der Engel Schar.

Kyrioleis

Maar het werd ook gezongen bij de lofzang op de opstanding van Christus, bij de lofzang op de Heilige Geest, bij het Avondmaal, en herhaalde malen in Die deutsche Litanei, een soort geloofsbelijdenis in gezongen gebedsvorm (Luther, 1950:25, 30, 32, 35, 48 v.v.).

Opvallend is dan de samengang tussen lofgezang en boetegebed. Danken en bidden gaan voortdurend samen. Het Kyrie eleison kwam ook al voor Luther voor in een Kerstlied uit de eeuw van de reformatie en dat lied ging terug op een oud Duits gezang uit de I lde eeuw:

$\mathrm{Nu}$ sis uns willekomen, herro Christ, du unser aller herro bist ...

Maar de geschiedenis van het Kyrie eleis is nog veel ouder. In de jaren 381-384 bevond de non Egeria, afkomstig uit een klooster op de grens van Frankrijk en Spanje, zich op haar pelgrimstocht in Jeruzalem. Zij maakte daar veel diensten mee onder leiding van bisschop Cyrillus van Jerusalem. Heel haar pelgrimage werd door haar neergelegd in een uitvoerig reisverslag. Zij verhaalt dan van de dagelijkse diensten in Jeruzalem 's middags om vieruur, waarin de bisschop optreedt en een van de diakenen voorgaat in gebed. "Daarna zingt een grote groep jongens telkens het 'Kyrie eleison' (bij ons, aldus Egeria, 'miserere Domine')" - Deddens 
(1975:94). Meermalen vermeldt Egeria dan dit Kyrie als onderdeel van de liturgie. Zijzelf kende alleen de Latijnse versie, maar het zou niet lang duren of de Griekse woorden zouden ook in het Westen ingeburgerd raken. Het is nl. zeer waarschijnlijk dat paus Gelasius tijdens zijn pausdom van 492-496 in het Westen heeft ingevoerd als onderdeel van het Ordinarium, dat aan de Schriftlezing voorafging (Brodde, 1958:174). De Griekse woorden werden dan gehandhaafd, en door paus Gregorius I (590-604) wordt gemeld deze woorden in zijn tijd ook wel afgewisseld werden met Christe eleison (Snijders, 1965/68:1424 v.v.). Men kent het Kyrie eleison ook uit Egypte, waar men het als morgengebed bad met het gezicht naar het Oosten, naar de opgaande zon. De Griekse uitdrukking is zowel in het Nieuwe Testament te vinden als in de Septuagint, de Griekse vertaling van het Oude Testament. Voor het Nieuwe Testament kunnen we verwijzen naar bv. Matteus 15:22 en 25 en 20:30 en 31, terwijl het in de Septuagint voorkomt bij Psalm 6:3; 9:14; 31:10; $41: 5$ en 11; 56:2; 6:3 en Jesaja 33:2.

Later wordt het in de Apostolische Constituties van de vierde eeuw genoemd als respons op het gebed van de diakenen en al heel vroeg werden zowel het Kyrie als Gloria genoemd als hymnen die hun plaats hadden in het begin van de liturgie. Het is dan ook typerend voor heel de liturgische instelling van Calvijn dat hij eveneens het Kyrie (en in feite ook het Gloria) aan het begin van de openbare eredienst plaatste. Niet de geestelijken, nee, de gemeenteleden moesten het zingen, maar Calvijn sloot sowel wat de zang als zodanig betreft als de plaatsing ervan, bewust aan bij de oude kerk. Het karakter ervan was heel duidelijk de bede om hulp tot de verhoogde Christus, om daadwerkelijk als kinderen van Gods verbond te leven naar Gods verbondswoorden.

\section{Vervolg van de dienst}

Het eerste gedeelte van de zondagmorgendienst in de Franse vluchtelingengemeente te Straatsburg sloot Calvijn af met de laatste zang van het Kyrie eleison na de laatste strofe van de berijming van de wet. Tot en met dit punt in de eredienst stond Calvijn voortdurend aan de tafel voor de kansel, met het gezicht naar de gemeente. Heel dit eerste gedeelte van de dienst stond in het teken van schuld, van Gods vergevende liefde, en van dankbaarheid daarvoor. Dan kwam het ogenblik dat de voorganger de 
kansel besteeg. Hij begon aan met een gebed om Gods zegen bij de opening van Gods Woord. Dat gebed hield ook in een bede om de verlichting door de Heilige Geest, die immers met dat Woord in de harten van Gods kinderen wil werken. Daarna werd Gods Woord geopend en een gedeelte gelezen. Bij Calvijn vormden Schriftlezing en prediking een ononderbroken en onlosmakelijk geheel. De andere elementen van de dienst (ook de bediening van de sacramenten) volgden na de prediking. Tot deze andere elementen behoorden het zingen van psalmen, de voorbeden, de collecte en ten slotte de zegen. Eventueel was er de bediening van de Doop en/of de viering van het Avondmaal, maar ook deze vonden plaats na de prediking, zoals gezegd.

Calvijn was wars van formalisme en automatisme, maar hij respecteerde de goede tradities van de kerk en voerde een zorgvuldig opgezette orde in, ook wat betreft het begin van de openbare eredienst, 'naar de gewoonte van de oude kerk'.

\section{Terug na Genève}

Meer dan eens ontving Calvijn in Straatsburg het dringende verzoek om naar Genève terug te keren en ten slotte voldeed hij daaraan. Maar hij kon in Genève nooit ten volle realiseren wat in Straatsburg wèl mogelijk was gebleken. Toen hij in Genève in het jaar 1541 terugkwam, werd hij opnieuw geconfronteerd met de liturgie van Farel, die hij al kende uit zijn eerste verblijf daar. Dat was een liturgie zonder gemeentezang en zonder frequente Avondmaalsviering. Calvijn had juist in Straatsburg het geweldige belang van de zang door de gemeente ontdekt en de berijming van de Psalmen was een geweldige vondst. Bovendien was hij sterk voor een frequente Avondmaalsviering, liefst zelfs elke zondag. Maar in Farels liturgie waren trekken die eerder aan Zürich dan aan Straatsburg deden denken, en Calvijn zette zich er nu voor in, de winst van Straatsburg niet verloren te laten gaan. Gedeeltelijk slaagde hij daarin, vooral op het punt van de gemeentezang, die hij uiterst belangrijk vond. Calvijn heeft zelf nog meegemaakt dat de complete Psalmberijming het licht zag, nl. twee jaar voor zijn dood. Maar op het punt van frequentere Avondmaalsviering slaagde hij niet. Het kwam ook niet tot een maandelijkse viering, zoals hij graag gewild had, maar de viering bleef beperkt tot vier maal per jaar. 
Daar legde hij zich ten slotte bij neer, zij het met grote tegenzin. Hij schreef daarover:

Toch heb ik in de openbare mededelingen laten vermelden, dat onze gewoonte abnormaal is (nl. de kwartaalsgewijze Avondmaalsviering), opdat het nageslacht ze gemakkelijker en vrijer zal kunnen verbeteren (Brienen, 1987:99).

Niet alleen ten aanzien van frequentere Avondmaalsviering, maar ook met betrekking tot andere punten van de liturgie kon Calvijn in zijn tweede periode in Genève niet gedaan krijgen wat hij graag gewild had. Eenzelfde berusting in de situatie van het heden, maar ook hoop voor de toekomst, is dan tekenend voor zijn houding. Het jaar nadat Calvijn is teruggekeerd naar Genève verscheen zijn liturgisch werk als een soort dienstboek voor de kerk te Genève, waaruit tevens duidelijk is dat hij wil aansluiten bij de gewoonte van de oude kerk (zie de titel van dit werk: Selon la coustieme de l'Eglise ancienne).

Het begin van de dienst is in deze liturgie als volgt: na het Votum (meervoudsvorm, naar Ps. 124:8) volgt geen groet, maar volgt de oproep:

Mijn broeders, laat elk van u zich voor het aangezicht van de Here stellen en zijn fouten en zonden belijden, door in zijn hart mijn woorden te volgen:

Here God, eeuwige en almachtige Vader, wij belijden en erkennen oprecht voor uw heilige majesteit, dat wij arme zondaren zijn, ontvangen en geboren in ongerechtigheid en verdorvenheid, geneigd om het kwade te doen, onbekwaam tot enig goed; en dat wij in onze verdorvenheid, zonder einde, zonder ophouden, uw heilige geboden overtreden. Daardoor halen wij, naar uw rechtvaardig oordeel, verderf en ondergang over ons. Maar, Here, wij hebben een mishagen over onszelf dat wij $U$ beledigd hebben, en wij veroordelen onszelf en onze zonden met waar berouw, begerende dat uw genade in ons onheil ons te hulp komt. Wil daarom, $O$ allergenadigste God en Vader, vol van barmhartigheid, in de naam van uw Zoon Jezus Christus, onze Here, erbarmen over ons hebben. En door onze zonde en smet uit te wissen, maak ons ervan vrij en vermeerder van dag tot dag de genade van uw Heilige Geest, opdat wij, onze ongerechtigheid van harte erkennende, bewogen mogen worden tot een mishagen dat ware boetvaardigheid in ons verwekt, die ons voor alle zonde dood maakt, en in ons vruchten van gerechtigheid en onschuld voortbrengt die $U$ aangenaam zijn door Hem, Jezus Christus, enz. (cf. Van Rongen, 1990:42).

In feite was deze schuldbelijdenis een van de gebeden uit 1537 van de hand van Bucer, zij het ook dat Calvijn er enige uitbreiding aan gaf. Heel 
duidelijk wordt dus begonnen met een belijdenis van schuld en Calvijn hechtte daar veel aan. Maar op de volgende punten was de orde die Calvijn in 1542 beschreef verschillend van de orde die hij in Straatsburg volgde:

* De woorden van troost na de belijdenis van schuld werden weggelaten.

* De woorden van absolutie kwamen niet meer voor.

* De wet werd niet meer gezongen maar gelezen.

* Het zingen van het Kyrie eleison na ieder wetswoord werd niet meer gedaan.

* De dienaar stond niet meer aan de tafel in het eerste gedeelte van de dienst, maar ging aanstonds naar de kansel.

Wat was de achtergrond van die veranderingen? Calvijn wilde de liturgie van Straatsburg wel gehandhaafd zien, maar het volk sprak van nieuwigheden. Ze waren inderdaad nieuw als men ze vergeleek met de liturgie van Farel, waaraan men nu gewend was, maar Calvijn wilde juist terugkeren naar een veel verder verleden: de oude kerk. Nu woog voor hem niet elk punt even zwaar. Maar de reformator van Genève hield vast aan de hoofdzaken van de eredienst, terwijl hij tevens zijn principe handhaafde dat men over de 'ceremoniën' geen blijvende strijd moest voeren. Maar evenals dat het geval was met een frequentere Avondmaalsviering, sprak hij bijvoorbeeld met betrekking tot de 'absolutie' de hoop uit, dan deze elders toch gehandhaafd zou worden. Veel later, op 12 augustus 1561, nog geen drie jaar vóór zijn dood, beantwoordt Calvijn de vraag naar 'bepaalde riten' in de kerk, en dan spitst hij het toe op schuldbelijdenis en genadeverkondiging:

Aan de openbare belijdenis der zonden een belofte toe te voegen, die de zondaren opwekt tot de hoop op vergeving en verzoening - er is wel niemand, die niet erkent, dat dit zeer nuttig is. En aanvankelijk heb ik dit gebruik ook willen invoeren: maar daar sommigen aanstoot vreesden vanwege de nieuwigheid, heb ik met groot gemak dit gebruik opgegeven. Dus is de zaak weggelaten. Nu hierin nog iets te veranderen zou niet van pas komen; want velen zijn al bezig op te staan, voordat men aan het slot van de zondenbelijdenis is toegekomen. Des te meer wensen wij, daar gij nog door 
niets gebonden zijt, het volk aan beide te gewennen (Calvijn, 1871:k 213/

214 - Ad quaestionem de quibusdam ecclesiae).

Het was toen in Genève nog de gewoonte knielend te bidden. Het lijkt Calvijn geen goede zaak toe, de absolutie alsnog in te voeren. Hij vreest kennelijk ook wanorde, nu de gemeente al bezig is op te staan terwijl de akte van schuldbelijdenis nog niet eens ten einde is. Maar belangrijk is de slotzin: laat men beide doen (schuldbelijdenis en een woord van zondenvergeving) als men nog moet beginnen en nog nergens aan gebonden is. Lekkerkerker (1949:138) legt nogal nadruk op het woord "opportuun zijn" ("van pas komen"), maar het komt ons voor dat de slotzin van deze passage van meer belang is.

Opgemerkt moet worden dat het steeds over de morgendienst gaat: voor de middagdienst, die een sterk lerend karakter had, gaf Calvijn geen orde. Calvijn bleef sterk vasthouden aan de verbinding van Schriftlezing en prediking, als een geheel.

Ten aanzien van de voorbeden, de collecte, het verdere zingen van de gemeente, alsmede de slotzegen, kon hij de orde blijven volgen die hij in Straatsburg al gewend was: dat alles moest gebeuren na de prediking. Dat de sacramenten bediend moesten worden na de preek had plaatsgevonden was voor Calvijn een duidelijke zaak en ook hierin hoefde geen verandering te worden aangebracht. Wat de orde van de Avondmaalsviering betref: Calvijn bleef daarin trouw aan de uiteenzetting ervan in zijn Institutie: de toebereiding van de elementen, de instellingswoorden, de afhouding, het gebed vóór het Avondmaal, de uitdeling van brood en wijn (met zingen of lezen), daarna de dankzegging en de lofzang voor God (Calvijn had de gewoonte aangenomen, de Lofzang van Simeon te laten zingen: "mijn ogen hebben Uw heil gezien"). Maar vooral ten aanzien van het begin van de dienst konden in Genève niet alles gerealiseerd worden wat Calvijn in de zin had.

\section{Vluchtelingengemeenten}

Betekende dit het eind van de elementen uit het begin van de dienst die in Genève geen doorgang vonden? Om te beginnen richten wij onze blik naar Engeland, en wel naar Londen. Daarheen was Maarten Micron gevlucht in het jaar 1549, zeven jaar na de publikatie van Calvijns liturgisch boek 
in Genève. In 1554, een jaar nadat hij Londen weer verlaten had, schreef hij zijn boek Christlicke Ordinancien, waaruit wij veel te weten komen over de eredienst van Hollandse vluchtelingengemeente in Londen in de jaren daarvóór. Het eerste deel van deze dienst bestond in feite alleen uit de opwekking om te bidden. Dat gebed eindigde met het Onze Vader en het zingen van een psalm. $N a$ de preek volgde de lezing van de Wet, dan de vermaning tot schuldbelijdenis, een gebed waarin die schuldbelijdenis was uitgedrukt, en ten slotte de proclamatie van de "binding en ontbinding van de zonden".

Enkele dingen vallen op. In de eerste plaats dat vrijwel heel het eerste deel van de dienst was verplaatst naar het tweede deel, namelijk na de preek. Verder: de belijdenis van schuld werd geplaatst na de lezing van de wet en zodoende kwam de wet wel helemaal te staan in het kader van de kenbron van ellende. De aansporing tot schuldbelijdenis was verwoord als volgt:

Wij zien in deze goddelijke wet als in een spiegel hoezeer en op hoeveel manieren wij God hebben beledigd met onze overtredingen; laat ons daarom van ganser harte begeren dat Hij ons wil vergeven met deze woorden ...

(Dan volgde het gebed om vergeving der zonden). Nieuw is de 'binding der zonden', de zogenaamde 'retentie-formule', geadresseerd aan degenen die zich niet van hun zonden bekeren:

Ik verklaar tot hen van het Woord van God, dat al hun zonden gebonden zijn in de hemel en niet ontbonden, totdat zij zich bekeren.

De absolutie of 'ontbinding der zonden' kwam wel terug, maar op een heel andere plaats dan in Calvijns liturgie van Straatsburg.

Was dit het algemene beeld van de vluchtelingengemeenten? Bedacht moet worden dat er, ook in Engeland, nog meer vluchtelingengemeenten waren. Zo was daar bijvoorbeeld ook de Waalse vluchtelingengemeente van Glastonbury. Daar werkte Vallérand Poullain, die in Straatsburg de opvolger van Calvijn was, maar die in 1549 samen met Bucer was uitgeweken naar Engeland. Sterker dan bij Micron is bij hem de invloed van Calvijn merkbaar. Hij publiceerde in 1551 zijn Liturgia Sacra. Daarin vinden wij ook de Liturgia diei dominici (de orde voor de dienst op zondag). Daarin vinden wij de volgende elementen wat het eerste deel van de dienst betreft:

* Zingen: het eerste gedeelte van de Tien Geboden. 
* Confessio peccatorum (belijdenis van zonden).

* Absolutio (vergeving van zonden).

* Zingen: het tweede gedeelte van de Tien Geboden.

* Kort gebed.

* Zingen: laatste couplet van de Tien Geboden.

Daarna volgden dan Schriftlezing en prediking (ook weer als één geheel). Het begin lijkt sterk op Calvijns orde, maar ook bij Poullain ligt het accent bij de wet sterk op de kenbron der ellende.

Toen 'Bloody Mary' in 1555 aan de regering kwam in Engeland, zijn Poullain, Micron en vele anderen naar het continent gevlucht. Poullain vervolgde zijn arbeid in Frankfurt, waar hij op dezelfde wijze de orde van dienst voortzette. (Zie over de vluchtelingengemeente uitvoeriger: Van Schelven, 1908: passim.)

\section{Andere landen}

In dezelfde tijd was John Knox predikant van de Engelse vluchtelingengemeente van Frankfurt. Een jaar later werd hij predikant van de Engelse vluchtelingengemeente van Genève en ontmoette hij Calvijn. Het daarop volgende jaar, 1555, publiceerde hij zijn liturgisch boek The Forme of Pravers and Administration of the Sacraments, etc., met de toevoeging: "gebruikt in de Engelse gemeente te Genève en goedgekeurd door de beroemde en godgeleerde man Johannes Calvijn".

Knox startte de dienst als volgt:

* Belijdenis van zonden.

* Gebed om vergeving van zonden.

* Zingen van een berijmde Psalm.

Daarna volgde het gebed om verlichting, lezing van de Schrift en prediking. Opnieuw is Calvijns invloed te bemerken: de dienst begon met verootmoediging, gevolgd door gebed om vergeving en een psalm die met vergeving had te maken. Slechts na de preek volgden de voorbeden, de Apostolische geloofsbelijdenis en de viering van het Avondmaal. Deze 
liturgie bleef in Schotland bestaan. Wat de Hongaarse gereformeerde kerken betreft: daar is de gewoonte gehandhaafd dat gedurende het zingen van Psalmen van verootmoediging, schuldbelijdenis en vergeving van zonden (met de Geneefse melodieën!) de predikant blijft zitten beneden de kansel. Na dit eerste gedeelte gaat hij de kansel op, zoals Calvijn in Straatsburg deed. Al betrof het niet alle elementen en dezelfde orde, maar duidelijk is wel Calvijns invloed naar buiten, ook al kon hij zelf niet buiten Straatsburg alles realiseren wat hij wel graag gewild had.

\section{Datheen en Nederland}

Wat de liturgie betreft, is er een duidelijke verbinding te leggen tussen Calvijn en de Nederlandse vluchtelingengemeente te Frankenthal in de Paltz onder leiding van Petrus Datheen. In 1562 werd deze de voorganger van deze vluchtelingengemeente. Datheen was ook in Londen geweest, maar was daar vertrokken in 1553, terwijl hij twee jaar later predikant werd van de Vlaamse vluchtelingengemeente van Frankfurt, waar hij ook Calvijn ontmoette. In Frankenthal bezorgde hij eerst een vertaling van de Heidelbergse Catechismus en daarna van de berijmde psalmen van Marot en Beza. In het laatste jaar van zijn verblijf in Frankenthal, 1566, verscheen zijn kerkboek. Daaruit kunnen wij opmaken hoe Datheen zich het begin van de zondagmorgendienst heeft gedacht. Hij ving aan met gebed en mogelijk ook met een zegengroet. Dan volgde het lezen of zingen van de wet. Het zingen ontleende hij aan Calvijn, het lezen aan Micron. Hij volgde ook Micron na op het punt dat de wet volledig in het teken stond van de kenbron van ellende. Want aanstonds na de wet volgt een opwekking tot boete en geloof in Gods beloften. Daarbij volgt hij niet een vaste formule, maar zegt: “... neemt de Kerckendienaer daer wt oorsaecke de Ghemeynte te vermaenen tot boete, ende bekentenisse haerer ouertredinghen, en te geloouen de Euangelische beloftenissen van Christo ...". Hierna volgen Schriftwoorden van vermaning en vertroosting, die uitlopen op woorden van retentie en absolutie, in die volgorde. Dan komt aan de orde het gebed vóór de predicatie (waarin het Apostolicum is opgenomen) en de bedezang voor de predicatie 'O Godt, die onse Vader bist'. Na de preek volgt dan het 'Gebedt voor alle nood der Christenheit', ook weer voorafgegaan door een schuldbelijdenis. Psalmgezang, zegen en collecte besluiten de dienst (Hendriks, 1970:223 v.v.). In veel opzichten 
lijkt deze orde op die van Calvijn in Straatsburg, alleen werd het accent zwaarder op de ellende gelegd, terwijl het Gloria ontbreekt.

Twee jaar na het verschijnen van Datheens kerkboek kwam het convent van Wezel samen, maar daar werd over Datheens orde geen uitspraak gedaan, evenmin als de synode van Emden van 1571 dat deed. Dat was wel het geval met de synode van Dordrecht 1574. Van deze synode was Gaspar van der Heyden praeses. Deze kreeg de opdracht, een korter gebed voor na de preek te ontwerpen. Verder werd de wet verplaatst naar de middagdienst en het gebed na de preek nam het Apostolicum over uit het gebed vóór de preek, terwijl het votum aan het begin van de dienst werd voorgeschreven. Orgelspel was contrabande. De synode beval wel de orde van Datheen verder aan, maar zweeg op het punt van de vermaning tot boete en geloof, de Schriftwoorden ter vermaning en vertroosting, en de binding en ontbinding van de zonden. Het is niet duidelijk of deze elementen gehandhaafd bleven of niet (Hendriks, 1970:253).

Petrus Datheen zat de synode van Dordrecht 1578 voor. Deze synode bracht geen wijziging in de liturgie, schreef de psalmberijming van Datheen voor, maar schrapte de bedezang vóór de prediking. De gezangen werden beperkt tot die welke ook in de Schrift gevonden worden. Gaspar van der Heyden presideerde weer de volgende synode, die van Middelburg 1581. Hij had inmiddels in 1580 een eigen liturgie ontworpen en de synode zette nu het mes in verschillende elementen uit Datheens liturgie.

In hetzelfde jaar was ook de psalmberijming van Marnix van St. Aldegonde verschenen en het gevolg was dat nu Datheens berijming niet meer voorgeschreven werd. Een reduktie werd toegepast op de zondagmorgendienst, die er zo kwam uit te zien: Schriftlezing, Psalmgezang, votum, gebed voor de predicatie, prediking, gebed na de predicatie, Psalmgezang, zegen, collecte. Twee dingen vallen op. In de eerste plaats werden Schriftlezing en prediking gescheiden door verschillende andere elementen, tegen de uitdrukkelijke wens van Calvijn. Verder werden retentie en genadeverkondiging geschrapt. Maar hoe gebeurde dat? 


\section{Niet na de preek}

Het is interessant, na te gaan hoe de synode van Middelburg 1581 er toe kwam, retentie en absolutie uit de liturgie te schrappen. Bij de 'particuliere vragen' was een vraag gesteld door de afgevaardigden van Gelderland:

Oft nyet goet ware des sondaechs na de predicatie opentlick ende int gemeyn den bekeeren den de vergeuinge ende den onboetueerdigen de bindinge der sonde te verkondigen.

De synode antwoordde daarop:

Ouermidts de bindyngne en ontbindinghe der zonden ghenouchsaem in de Predicatie des woordts geschiedet, dat het daeromme onnoodich is, een eyghen forme daer toe in te voeren.

$\mathrm{Nu}$ valt het op, dat de vraag van Gelderland spreekt over retentie en absolutie $n a$ de preek. Dat werd wel eerder gedaan, maar dan was dat in de regel in verband met het daaropvolgende Avondmaal. Die regel bestaat nog steeds, namelijk in het Formulier voor de viering van het Heilig Avondmaal (ook in het Korte Formulier). Daarin komen na de zelfbeproeving zowel 'nodiging' als 'terugwijzing' voor. Maar slechts in één op de dertien gevallen volgde op zondagmorgen een Avondsmaalsdienst. Daarom is het antwoord van de synode wel begrijpelijk, dat een aparte formule van absolutie en retentie na de preek niet zo zinvol is. Maar de liturgie van Calvijn in Straatsburg, nagevolgd door Datheen, plaatste juist deze elementen aan het begin van de dienst, als beantwoording van de vraag: hoe komen wij als gemeente van Christus samen? Volle nadruk kwam dan te liggen op de schuldbelijdenis en de noodzaak van zondevergeving. Maar het antwoord van de synode van 1581 moet vooral worden gelezen tegen de achtergrond van de liturgie van Gaspar van der Heyden, die de Calvijnse liturgie van Datheen had gereduceerd en in feite uitgehold. Kuyper (1899:394) stelt dat reeds de synode van 1574 de liturgie in den grond heeft bedorven. Nog sterker is dat te zeggen van de synode van 1581 .

Daarachter ligt dan weer de ontwikkeling van de liturgie die terug gaat op Zürich en vandaar een weg gevonden heeft naar Micron in Londen en in de Pfaltz, waarin genadeverkondiging (en eventueel retentie) na de prediking 
een plaats had, maar die niet overeenkomstig de lijn Straatsburg en Frankenthal was.

Opmerkelijk is trouwens dat ook ná 1581 in verschillende uitgaven van de liturgie de absolutie en de retentie bleven afdrukken. Zo kan men die vinden in de Hackius-bijbeluitgave van 1596 en ook nog in de Elzevieruitgave van 1617, al werd dit dan niet meer ondersteund door synode-besluiten. (Zie verder De Jong, 1957:167 v.v. en ook Bakker, 1960:18 v.v.)

Wijzigingen deden zich niet voor ter synode van 1586 te 's Gravenhage wat de orde van dienst betreft. Alleen werden aan de Formulieren toegevoegd die ter bevestiging van de kerkelijke ambtsdragers en ter oefening van kerkelijke tucht.

De synode van Dordrecht 1618/19 liet de herziening van de liturgie over aan een commissie, maar in feite kwam het niet tot herziening. De synode zelf deed niet veel meer dan het geven van haar sanctie aan de liturgie als zodanig en bepaalde dat tot haar behoren: de openbare gebeden, de formulieren voor de bediening van Doop en Avondmaal, de formulieren van ban en wederopneming, de bevestigingsformulieren en het huwelijksformulier.

Het is te bejammeren, dat de commissie geen uitgave heeft bezorgd, of liever nog dat de Synode zelve geen tijd heeft kunnen vinden voor eene ernstige behandeling dezer zaak. Eene revisie der liturgie mag dit niet heeten. Dan had ook gezorgd moeten worden voor eene weloverwogen volgorde in de godsdienstoefeningen, die wij nu ten eenenmale missen (Biesterveld, 1903:163).

\section{Vernieuwing?}

$\mathrm{Na}$ de Dordtse Synode van $1618 / 19$ brak er een lange periode van stilzwijgen aan met betrekking tot de gereformeerde liturgie in het algemeen en de orde van de dienst in het bijzonder. In 1773 werd Datheens Psalmberijming vervangen door de 'Statenberijming' die ook al spoedig weer kritiek uitlokte. Toen de 'Evangelische Gezangen' in 1807 werden ingevoerd, leidde dat spoedig tot veel moeilijkheden. De Psalmen werden naar de achtergrond gedrongen en weinig Schriftuurlijke gezangen kwamen er voor in de plaats. Het was vooral A. Kuyper die met zijn artikelen in De Heraut (in 1911 in uitgebreidere vorm in Onze Eeredienst 
gebundeld) aan het eind van de vorige eeuw de gereformeerde eredienst nieuw leven inblies. Hij stelde tal van verbeteringen voor. In het kader van ons onderwerp noemen wij speciaal zijn voorslag om de absolutie opnieuw in te voeren:

$\mathrm{Na}$ de Schuldbelijdenis moet volgen de Absolutie, d.w.z. aan de vergadering der geloovigen moet in den Naam des Heeren de vergeving harer zonden worden betuigd en aangekondigd, en aan de ongeloovigen, die in de vergadering der geloovigen zich mengden, moet worden aangezegd dat hun zonde (met ingesloten hun erfschuld) voor hun persoonlijke rekening blijft liggen, en dat deswege hun stellig en gewisselijk de eeuwige verdoemenis te wachten staat, tenzij ze door zich te bekeeren, het zegel van hun vrijspraak van God zelven ontvangen mochten (Kuyper, 1911:241).

Kuyper is dus ook voor de retentie. Hij haalt met instemming de formules aan die door A Lasco in Engeland al in gebruik waren, maar hij waarschuwt tevens voor "elk machinaal verrichten van deze actie" (Kuyper, 1911:244, 256). W. Heyns had in Grand Rapids de artikelen van Kuyper in De Heraut al gelezen en hij betuigde er in zijn Liturgiek telkens zijn instemming mee. In dat verband schrijft hij ook:

Het zou zeer tot zegen kunnen zijn, wanneer in deze belijdenis en absolutie, als een apart cultus element, het door God gelegd verband tusschen boetvaardigheid en geloof ter eene en vergeving der zonden ter andere zijde en het openen en toesluiten van het Koninkrijk der Hemelen door den sleutel van den dienst des Woords naar antw. 84 van den Heid. Cat. op nadrukkelijke en sprekende wijze tot uiting werd gebracht (Heyns, 1903:161).

Blijkbaar brengen zulke vragen ook meer leven in de kerken. De synode van Leeuwarden 1920 benoemde deputaten voor de herziening van de liturgie. Zij boden hun rapport aan de synode van Utrecht 1923 aan. Daarin stelden zij voor, de verbinding tussen Schriftlezing en prediking in ere te herstellen, en ook om de absolutie weer in te voeren na de schuldbelijdenis, die plaats zou vinden na de lezing van de wet en het zingen door de gemeente van het Gebed des Heren: "Vergeef ons onze schulden, Heer ...". Daarna zou de dienaar spreken:

Allen, die oprecht berouw hebben over hunne zonden en hunne toevlucht nemen tot den eenigen Zaligmaker Jezus Christus, verkondig ik de vergeving der zonden in den naam des Vaders en des Zoons den des Heiligen Geestes, Amen (Rapporten, 1923:140). 
Hierna zou geen retentie-formule volgen, maar het gebed met de voorbeden. Intussen was ook T. Hoekstra, de hoogleraar ambtelijke vakken te Kampen, het met $\mathrm{A}$. Kuyper eens dat de absolutie weer ingevoerd moest worden. In Canada kon ik een exemplaar bemachtigen van zijn Dictaat Liturgiek voor het jaar 1921/22, waarin te lezen valt:

De absolutie is, evenals de confessio peccatorum, als zelfstandig deel van den eeredienst in onbruik geraakt, wat zeer te betreuren is, omdat zoowel uit algemeen liturgisch oogpunt, als om historische redenen, de absolutie zulk een uitnemende plaats inneemt ... Het is zeer gewenscht, dat deze opnieuw wordt ingevoerd. In de eerste plaats om historische reden, omdat de beste liturgieën dit element hebben en in de tweede plaats om den eeredienst zelf. leder Christen gevoeld, dat er een ontzaglijke afstand is tusschen God en ons, zondaren. Al zijn we geloovigen en hebben we vrede in het hart, toch klaagt onze conscientie ons aan. En nu moet in den aanvang van den eeredienst aan den geloovige, die berouw heeft, ook cultisch in de liturgie de verzekering worden gegeven, dat God zijn zonden wegneemt opdat hij de volle schuldvergeving zich kan toeëigenen. Dit element moet om deze reden blijven. De prediking is een publieke absolutie en retentie en niet alleen vertroosting en bedreiging, maar een betuiging in den Naam des Heeren, dat den geloovigen de zonden vergeven en den ongeloovigen ze gehouden zijn. Maar naast deze absolutie moet er ook een absolutie zijn als zelfstandig element in den eredienst (Hoekstra, 1921/1922:24 v.v.).

Maar de synode Utrecht 1923 wees de voorstellen van de deputaten af. Alles bleef zoals het was, ook ondanks het pleidooi van A. Kuyper en T. Hoekstra. Maar ook na 1923 verstomden de stemmen niet die herinvoering van de absolutie bepleitten. In een niet-uitgegeven Catechisatiedictaat voor cursus 1929/30 van wijlen mijn vader, toen predikant te Rijswijk, staat onder Liturgie of orde van den publieken eeredienst een pleidooi om zowel de absolutie als de retentie weer in te voeren, en ook een hereniging van Schriftlezing en prediking als een geheel, terwijl ook de gedachte van de regel der dankbaarheid bij de wet benadrukt wordt.

Over de wetsverkondiging:

De wetslezing dient om de gemeente voor te houden de dankbaarheid waartoe zij verplicht is om Christus' verlossingswerk. Juist in dit stuk der dankbaarheid leeren wij hoe ontzaglijk veel wij te kort komen en leeren wij hoe langer hoe meer onze zondige aard kennen.

Over de absolutie of vergeving der zonden: 
$\mathrm{Er}$ is reeds een verkondiging van schuldvergiffenis in de bediening van het Woord. Toch is die verkondiging van schuldvergeving ook noodig als aparte handeling van den eeredienst. Het zijn immers onze zonden die scheiding maken tusschen God en onze ziel. Maar zoodra wij onze schuld belijden, wordt ze door God vergeven. Daarom past ons na schuldbelijdenis de absolutie als verklaring van Godswege dat dan boetvaardige om Gods wil de schuld is vergeven, maar dat den onboetvaardige de zonden worden gehouden.

Dit dictaat is gegeven na de afwijzende beslissing van de synode van Utrecht 1923 en vóór de beslissing van Middelburg 1933 inzake de liturgie. Maar deze laatste synode drukte alleen maar de reeds in de praktijk bestaande orde van dienst af, en besloot verder alleen de Gezangen uit te breiden tot 29. Er werd niets veranderd in de orde van dienst.

\section{Na de vrijmaking}

Wat de periode van na de vrijmaking betreft: in 1972 benoemde de synode van Hattem een drietal deputaten om de orden voor de eredienst kritisch te bezien en zo nodig te herzien. Deze deputaten hebben aan de synode van Kampen 1975 een tweede orde van dienst gepresenteerd, naast die van Middelburg 1933. Deze orden (voor de morgen- en ook een voor de middagdienst) sluiten veel nauwer aan bij de Calvijnse orde, vooral op het punt van de samenhang van Schriftlezing en prediking, en de plaats van de gebeden (schuldbelijdenis en gebed om verlichting met de Heilige Gees, voor de preek en de voorbeden na de preek). De voorstellen zijn aangenomen door de synode. Zelf deeluitmakend van dit deputaatschap vind ik het achteraf jammer dat niet voorgesteld is, het begin van de dienst nog verder te veranderen, dan wel nog een derde orde te hebben voorgesteld om absolutie en retentie opnieuw een plaats te geven. Ongetwijfeld was het waar wat het rapport vermeldt, namelijk dat de genadeverkondiging in de preek tot zijn recht komt. Maar de vraag kan ook gesteld worden: sluit het een het ander uit? Calvijn, Datheen, A. Kuyper en T. Hoekstra hadden kennelijk dat oordeel niet. Komt dan tweemaal hetzelfde element in de liturgie voor? Maar de plaats is verschillend en de invalshoek eveneens. En komen andere elementen ook niet terug op andere plaatsen in de liturgie en eveneens met verschillende invalshoek? Men denke aan het zingen van de gemeente (doorgaans 
minstens vijf maal per dienst) en de gebeden, die ten minste twee maal plaats vinden. Bovendien: wij hebben ook in de Avondmaalsformulieren een typische absolutie en retentie in de 'Nodiging en terugwijzing', zoals wij al zagen. De nodiging wordt ingeleid met: "Allen dan die door de genade van God bedroefd zijn over hun zonden ..." en de terugwijzing met: "Maar ieder die geen droefheid over zijn ongerechtigheid kent ...". Maar die absolutie en retentie vindt dan slechts vier maal of hooguit zes maal per jaar plaats. Het argument wordt wel gebruikt dat deze nodiging en terugwijzing geplaatst zijn in het kader van de zelfbeproeving. Maar dan kan de vraag gesteld worden: dienen wij ons allen niet voortdurend te beproeven? Is de hele zaak van de zelfbeproeving beperkt tot de tijd dat er weer een Avondmaalsviering in zicht is? Wat dat betreft, wil ik wijzen op het liturgisch-onjuiste gebruik in sommige kerken om het Avondmaalsformulier in twee delen te knippen. Men leest dan het eerste gedeelte tot en met de zelfbeproeving alsmede de nodiging en terugwijzing op de zogenaamde voorbereidingszondag, en vervolgt dan het tweede gedeelte op de Avondsmaalszondag zelf. De vraag is trouwens of er een aparte voorbereidingszondag moet zijn. Wanneer de absolutie en retentie opnieuw wordt opgenomen in de zondagmorgenliturgie, dan zou kunnen blijken hoe heilzaam de steeds weerkerende vermaning tot zelfbeproeving is. Daarbij mag geen sprake zijn van werktuiglijkheid of vormendienst, maar dat geldt natuurlijk voor alle elementen in de liturgie. Een gevaar voor automatisme of formalisme zou ook heel goed bezworen kunnen worden door niet één vaste formule of slechts één bepaalde tekst te gebruiken. De Schrift is rijk genoeg om de gedachte van schuldbelijdenis en vergeving van de zonden uit te drukken. Wij stemmen in met J.J. van der Walt als hij schrijft:

Die hoofdinhoud van die Formuliergebed voor die preek is belydenis van sonde. Dit moet geskied in kort volsinne, rustig, sodat die gemeente kan saam bely, konkreet maar nie persoonlik nie, eenvoudig en kinderlik. Die taal en toon moet dié wees van een wat midde in die skuld staan ... (Van der Walt, 1982:55).

Maar het mooiste zou zijn als er weer twee gebeden zouden zijn vóór de prediking (behalve de bede om hulp aan het begin van de dienst): de schuldbelijdenis en de bede om verlichting met de Heilige Geest. 


\section{Enkele voorbeelden}

Een fraai voorbeeld van afwisseling in de elementen van schuldbelijdenis en absolutie vinden we in het Handboek vir die erediens van die Nederduitse Gereformeerde Kerk van Zuid-Afrika. Vier punten volgen onder het hoofdstuk: "Verootmoediging en skuldbelydenis":

1. Daar moet groot erns gemaak word met hierdie belangrike element sodat dit nie afslyt en in 'n blote roetine verval nie. Daarom moet dit sorgvuldig voorberei word en met afwisseling geskied

2. Wanneer die verootmoediging en skuldbelydenis in die vorm van sang deur die gemeente geskied, moet die lied afgewissel word. 'n Keuse kan uit byvoorbeeld die volgende gemaak word (dan volgen een aantal coupletten uit zeven Psalmen, nl. 6, 25, 32, 38, 51, 53 en 130 en ook uit 17 gezangen van hun bundel - K.D.).

3. Die liturg kan aan die hand van die gepaste Bybeltekste die gemeente op verantwoordelike wyse in verootmoediging en skuldbelydenis voorgaan.

4. Skrifgedeeltes wat gebruik kan word met die oog op die opwekking tot verootmoediging en skuldbesef: Esra 9:5-10; Psalm 32:2-5; Psalm 38:1-5; Psalm 51:3-14, 19; Psalm 130; Jesaja 59:1-3; Jakobus 4:3-10; 1 Petrus 1:13-25; 1 Johannes 1:52:5; 1 Johannes 2:15- 17.

Dan volgt de genadeverkondiging en retentie: dit geskied deur die volgende formule deur die liturg:

Aan almal wat met ' $n$ ware berou en opregte geloof hulle toevlug neem tot hulle enigste Verlosser, Jesus Christus, verkondig ek in die Naam van die Here / verkondig die Woord van God die vergifnis van sonde.

Hierby kan gepaste tekste soos 1 Johannes 1:9; Esegiel 36:26, 27; Romeine S:1; Romeine 8:1, 2, ensovoorts, gelees word.

Wat de vermaning of retentie betreft, vervolgt de dienaar:

Maar aan elkeen wat in die sonde volhard en die genade verwerp, verkondig ek in die Naam van die Here / verkondig die Woord van God dat die toorn en straf van die Here op hom bly solank hy in die sonde bly lewe.

Hierby kan tekste soos Johannes 3:18, 36; Hebreërs 10:28, 29 gelees word (Handboek, 1988:22 v.v.). 
Van belang is hier de meervoudige keus, zowel in de formules als in het tekstgebruik. Als voorbeeld van een verbetering van het eerste deel van de zondagmorgendienst willen we ook wijzen op de suggestie van $G$. van Rongen. Na 'Votum' en 'Begroeting' is z.i. een 'Amen', gezongen door de gemeente, op zijn plaats. Wat de 'Wetslezing' betreft, is Van Rongen voorstander van afwisseling (bijvoorbeeld eens per maand de woorden van Deuteronomium 5), maar tegenstander van het tevens lezen van de 'hoofdsom' uit Matteus 22. "De hoofdsom is exegese, niet de wet zelf?" (Van Rongen, 1990:28; zie ook breedvoeriger hierover: Schilder, 1981:269 v.v.). De Here Jezus gaf de samenvatting in een andere context, $\mathrm{nl}$. in een dispuut met de Farizeërs. Exodus en Deuteromium 5 geven de constitutie van Gods verbond. Van Rongen (1990:204) wil bij de wetslezing benadrukken dat hier aan de orde is de regel der dankbaarheid, ook de kenbron van ellende, maar tevens de verbondsvernieuwing. Hij pleit er voor, aan Exodus 20 af en toe de lezing van Exodus 19:3-6 vooraf te laten gaan, "de proclamatie van het verbond van Sinai". Ook van Rongen wenst de eenheid van Schriftlezing en prediking te herstellen, na openbare schuldbelijdenis, met genadeverkondiging en retentie, en na een afzonderlijk gebed om verlichting door de Heilige Geest.

Hij geeft vijf mogelijkheden aan voor schuldbelijdenis, absolutie en retentie, die ook afgewisseld kunnen worden:

1. De formules in de liturgie van Bucer.

2. De formules in de Straatsburgse liturgie van Calvijn.

3. De manier waarop men het in de Paltz deed.

4. Wat in het rapport voor de synode van 1923 werd voorgesteld: het gebed van Bucer en Calvijn' gevolgd door gemeentezang van het Gebed des Heren (Gezang 5) vers 6.

5. 'Het gebed van Bucer en Calvijn' gevolgd door een formule die ontleend is aan Zondag 31 van de Catechismus.

Bij 1, 2, 3 en 5 kan dan na de formules een psalm of gezang worden gezongen (Van Rongen, 1990:205). Wij juichen deze voorslagen van harte toe, ook wat de variaties betreft. Wij zijn van oordeel dat deze zaken in de lijn van Calvijn liggen, hun wortels hebben in de oude kerk en een verrijking van de dienst op zondagmorgen betekenen. 
Dringt op deze wijze niet des te meer tot de gemeente door wat de rijkdom is in de ontmoeting met de levende God? Ik wil ook graag instemmen met de voorslag van Van Rongen om de tweede dienst op zondag het aloude catechetische karakter terug te geven. Wel vraag ik mij af of het dan nodig is, de geloofsbelijdenis te verplaatsen naar de morgendienst, na het voorbedengebed en de dienst der barmhartigheid. Het lijkt me juist, de openbare schuldbelijdenis met de genadeverkondiging en retentie te beperken tot de zondagmorgendienst. Maar mijn vraag is: wordt de tweede dienst niet al te sober als ook het Apostolicum (liefst gezongen door de gemeente) daar uit verwijderd wordt? Graag stem ik er mee in dat de beide diensten niet verwisselbaar zijn, omdat ze een verschillend karakter hebben. Niet dat de tweede dienst geen dienst des Woords zou zijn, maar wel: het catechetisch karakter van deze dienst staat toch wel op de voorgrond. (Zie ook Van Dooren, 1980:55 v.v.)

\section{Conclusies}

Samenvattend kom ik tot de volgende conclusies:

1. Het was een belangrijk en lofwaardig principe van Calvijn dat hij in liturgisch opzicht verbinding zocht:

* met wat hij vond in de Heilige Schrift;

* met de gewoonte van de oude kerk;

* met goede gewoonten die zich in de loop van de geschiedenis had ontwikkeld.

2. Hoofdzaak was voor hem wat hij al in zijn Institutie had gesteld, namelijk dat de eredienst in elk geval de elementen van lezing en prediking van Gods Woord, bediening van de sacramenten, gebeden (inclusief zingen door de gemeente) en dienst der barmhartigheid moest bevatten.

3. Calvijn verklaarde zich niet tegen vormen in de eredienst; hij was ook voorstander van een goede orde, maar hij kon ook minder belangrijke elementen achterwege laten, wanneer de eenheid en vrede van de kerk dat vereisten. 
4. Het eerste deel van Calvijns liturgische orde, zoals hij die in Straatsburg kon realiseren (het gedeelte voor het gebed om de opening van Gods Woord en de verlichting door de Heilige Geest) vormt een organisch geheel overeenkomstig de trits: ellende, verlossing en dankbaarheid.

5. Terecht benadrukte Calvijn sterk de gedachte van verootmoediging, aanstonds aan het begin van de eredienst.

6. Deze ootmoedigheid wordt uitgedrukt in de belijdenis van zonden, die aanstonds wordt gevolgd door een woord van vertroosting uit Gods Woord en de verklaring van vergeving aan het adres van de gelovigen.

7. Het is gewenst, aan de belofte van vergeving ook een woord van vermaning toe te voegen aan het adres van de onbekeerlijken.

8. Het argument dat de verkondiging van de vergeving der zonden reeds in de prediking tot zijn recht komt en dus voor het overige overbodig is, kan worden bestreden om de volgende redenen:

* Het zou meer steek houden als het ging om een woord van vergeving aanstonds $n a$ de preek.

* $\quad$ Er zijn meer elementen in de dienst die meer dan eens plaats vinden, zoals de gebeden en het zingen.

* Behalve de verkondiging van de vergeving in de prediking en de terughouding van de ongelovige, vinden de elementen van absolutie en retentie ook plaats in het Formulier voor de viering van het Avondmaal.

9. Wanneer de elementen van absolutie en retentie opnieuw zouden worden ingevoerd, dient men variatie in acht te nemen: de Heilige Schrift biedt een veelheid van teksten, die kunnen worden afgewisseld.

10. Te weinig heeft men zich gerealiseerd dat (het zingen van) de wet bij Calvijn de dankbaarheid tot uitdrukking bracht en in de plaats kwam van het Gloria. 
11. Het besef moet weer levendig worden dat de aanvang van de wet Gods een belofte bevat en een eenheid vormt met de tien verbondswoorden: samen vormen de beloften en de eisen van Gods verbond de Constitutie van Gods verbond.

12. Vanwege deze eenheid van belofte en eis van Gods verbond in Exodus 20 en Deuteronomium 5 is een herhaling van de wet in de lezing van een 'hoofdsom' overbodig:

* Wanneer Christus deze hoofdsom geeft is dat in een andere context, namelijk in een dispuut met de Farizeërs.

* Deze hoofdsom geeft een exegese van de wet en is niet zozeer de wet zelf.

* Een herhaling van de wet met een hoofdsom laat het karakter van de belofte van Gods verbond in het kader van de eredienst achterwege.

13. Calvijn had een bijzondere reden voor het laten zingen van het Kyrie eleison na elk van de tien geboden, namelijk de steeds herhaald bede om hulp ten einde de dienst van God in liefde en dankbaarheid te kunnen uitrichten; dit zou ook op een andere wijze tot uitdrukking kunnen worden gebracht na de lezing van de Constitutie van Gods verbond.

14. Calvijn stond een frequentere Avondmaalsviering voor dan slechts vier maal per jaar; zijn (latere) ideaal van een maandelijkse viering zou heden ten dage gemakkelijk gerealiseerd kunnen worden; wanneer absolutie en retentie opnieuw zouden worden ingevoerd, dan kon een 'voorbereidingszondag' des te gereder worden gemist.

15. Met het oog op het bijzondere karakter van de tweede dienst op zondag, namelijk de nadruk op het catechetisch karakter ervan, is het juist, het eerste gedeelte van de dienst van zondagmorgen te beperken tot die morgendienst en ook geen verwisseling van morgen- en middagdienst te doen plaatsvinden. 


\section{Bibliografie}

BAKKER, J.T. 1960. Vragen rond de genadeverkondiging. In Jaarboek voor de eredienst van de Nederlandse Hervormde Kerk. 's Gravenhage : Boekencentrum. p. 18-33.

BIESTERVELD, P. 1903. Het Gereformeerde Kerkboek. Zutphen : Traktaatgenootschap "Filippus".

BRIENEN, T. 1987. De liturgie bij Johannes Calvijn. Kampen : De Groot Goudriaan.

BRODDE, O. 1958. Ordinarium. In Evangelisches Kirchenlexikon II. Göttingen : Vandenhoeck \& Ruprecht. k. 1714-1716.

CALVIJN, J. 1871. Calvini Opera. Ed. Baum-Cunitz-Reuss X-1. Brunsvigae :C.A. Schwetschke et fil.

CALVIJN, J. z.j. Institutie of onderwijzing in de Christelijke godsdienst. (Vert. A. Sizoo.) Delft : Meinema.

CALVIJN, J. 1542. La Forme des Prieres et Chantz Ecclesiastiques, aucec la maniere d' administrer les Sacremens, \& consacrer le Mariage: selon la coustume de l'Eglise ancienne. Facs. uitg. Pierre Pidoux, Montreux, 1959.

DANKBAAR, W.F. 1978. Hervormers en humanisten. Amsterdam : Ton Bolland.

DEDDENS, K. 1975. Annus Liturgicus? Een onderzoek naar de betekenis van Cyrillus van Jeruzalem voor de ontwikkeling van het 'kerkelijk jaar'. Goes : Oosterbaan \& Le Cointre.

DEDDENS, K. 1990. Fulfil Your Ministry. Winnipeg, Manitoba, Canada : Premier Publishing.

DEDDENS, P. 1929/1930. Dictaat Catechisatie. Rijswijk : niet uitgegeven.

DE JONG, F. 1957. Bindinghe en ontbindynghe der zonden. Een poging tot verstaan van een Synodebesluit. (In Kerk en Eredienst, XII. 's Gravenhage : Boekencentrum. p. 167-180.)

GEREFORMEERD KERKBOEK. 1986. Haarlem : Vijlbrief.

HANDBOEK EREDIENS. 1988. Handboek vir die erediens van die Nederduitse Gereformeerde Kerk. Goodwood, Kaap : NG Kerk-Uitgewers.

HASPER, H. 1955. Calvijns beginsel voor den zang in den eredienst, I. 's Gravenhage : Martinus Nijhoff.

HENDRIKS, A.N. 1970. Datheens Liturgie van 1566 en de besluiten der Nederlandse Nationale Synoden 1568-1581 met betrekking tot de orde van dienst voor de zondagmorgen. (In Almanak van het Corpus Studiosorum in Academia Campensi "Fides Quadrat Intellectum". Kampen : Zalsman.

p. 223-264.) 
HEYNS, W. 1903. Liturgiek. Ten dienste van de studenten aan de Theologische School der Christelijke Gereformeerde Kerk te Grand Rapids, Michigan. Holland, Michigan : Holkeboer.

HOEKSTRA, T. 1921/1922. Dictaat Liturgiek. Kampen : Studenten-uitgave.

KRUIJF, E.F. 1901. Liturgiek. Ten dienste van dienaren der Nederlandsche Hervormde Kerk. Groningen : Wolters.

KUYPER, A. 1911. Onze eeredienst. Kampen : Kok.

KUYPER, H.H. 1899. De post-Acta of nahandelingen van de Nationale Synode van Dordrecht in 1618 en 1619 gehouden. Amsterdam/Pretoria : Höveker \& Wormser.

LEKKERKERKER, A.F.N. 1949. De reformatie in de crisis. Wageningen : Veenman \& Zonen.

LUTHER, M. 1950. Geistliche Lieder. München : Chr. Kaiser.

MACDONALD, A.B. 1935. Christian Worship in the Primitive Church. Edinburgh : Clark.

MAXWELL, W.D. 1952. An Outline of Christian Worship. London : Oxford University Press.

RAPPORTEN SYNODE. 1923. Rapporten aangeboden aan de Generale Synode te Utrecht. Kampen : Kok.

RUTGERS, F.L. 1889. Acta van de Nederlandsche Synoden der zestiende eeuw. 's Gravenhage : Nijhoff.

SCHILDER, H.J. 1981. Het kerkschip biedt behouden vaart. Kampen : Van den Berg.

SNIJDERS, A. 1965/1968. Kyrie eleison. (In Liturgisch Woordenboek II. Roermond : Romen \& Zonen. k. 1424-1427.)

VAN DER WALT, J.J. 1982. Soek die Here in sy tempel. Potchefstroom : Potchefstroomse Publikasies.

VAN DOOREN, G. 1980. The Beauty of Reformed Liturgy. Winnipeg, Manitoba, Canada : Premier Publishing.

VAN RONGEN, G. 1990. Met al de heiligen. Liturgie in hemel en op aarde, III. 'Zijn gemeenschap': de gereformeerde liturgie. Bameveld : De Vuurbaak.

VAN SCHELVEN, A.A. 1908. De Nederduitsche vluchtelingenkerken der XVle eeuw in Engeland en Duitsland. 's Gravenhage : Nijhoff.

WEBBER, F.R. 1938. Studies in the Liturgy. Erie, Pennsylvania : Ashby Printing Company.

WEGMAN, H.A.J. 1976. Geschiedenis van de Christelijke eredienst in het Westen en in het Oosten. Een wegwijzer. Hilversum : Gooi en Sticht. 
WEISMANN, E. 1956. Der Predigtgottesdienst und die verwandten Formen. (In Leiturgia III. Handbuch des evangelischen Gottesdienstes. Kassel : Stauda. p. 1-97.) 
